\title{
INFLUENCE OF SOME TRACE MINERALS IN FORM OF NORMAL AND NANO PARTICLES AS FEED SUPPLEMENTATION ON GROWING RABBIT DIETS
}

\author{
Fatma T.F. Abd-El Ghany ${ }^{1}$; M.F. Zawrah ${ }^{2}$ and M.Y. Mohmed ${ }^{1}$ \\ ${ }^{1}$ Animal Production Research Institute, Agricultural Research Center, Ministry of Agriculture, Dokki, \\ Giza, Egypt. \\ ${ }^{2}$ National Research Centre, Center of Excellence for Advanced Sciences, Advanced Materials and \\ Nanotechnology Group 12622 Dokki, Cairo, Egypt.
}

(Received $7 / 11 / 2016$, Accepted $20 / 12 / 2016$ )

\section{SUMMARY}

$\mathrm{T}$

This study was conducted to evaluate effect of adding some trace minerals (copper, zinc and selenium) in Normal and Nano form in a half of amount. Seven diets adding with Control (0), 1g Normal copper $\mathrm{Cu}$, 0.5g Nano-Cu, 0.8 Normal Zinc (Zn), 0.4 g Nano- Zn, 0.2 Normal selenium (Se) and $0.1 \mathrm{mg}$ Nano-Se $/ 100 \mathrm{~kg}$ of diet, respectively. Eighty four New Zealand White (NZW) growing rabbits (5 weeks old) with an average weight of $565 \mathrm{~g}$ were randomly assigned individually to seven treatments of twelve rabbits each. All diets were formulated to be iso-protein and iso-digestible energy, and to satisfy the nutrients requirements according to Agriculture Ministry Decree (1996) recommendation. The experimental lasted for 8 weeks. The results showed that nano form of trace minerals used have more improving in live body weight, body weight gain and feed conversion. There are no significant differences in dry matter digestibility and organic matter digestibility between groups. The digestion coefficients of different nutrients and nutritive values of diets contained trace minerals $(\mathrm{Cu}, \mathrm{Zn}$ and $\mathrm{Se})$ were significantly $(\mathrm{P} \leq 0.05)$ better in general than control group. Groups supplemented with Nano- $\mathrm{Cu}$, Nano- Ze and Nano- Se were the best one's in the digestion coefficients of different nutrients and nutritive values between all groups. Diets had significant $(\mathrm{P} \leq 0.05)$ effect on carcass traits, highest cecum weight and Total edible parts were in group supplemented with Nano-Se. Also, the highest liver and heart weight were in group supplemented with Nano-Se. Data showed that rabbit fed diet supplemented with Nano-Se increased significantly $(\mathrm{P}<0.05)$ in total protein, glucose and total antioxidant capacity. Results also, showed that least cecum microbial counts, in general were noticed with Nano-Se group. Yeast counts increased when compared with the control diet except normal-Cu group. The least feed cost/ $\mathrm{Kg}$ body weight gain, economic efficiency and the best relative economic efficiency were for $\mathrm{Nano-Cu}$ supplementation, while the worst values were for control. The all diets for normal and nano trace minerals were better than the control diet. In conclusion, adding copper, zinc and selenium in normal form and nano form in even a half of amount in growing rabbit diets can be used economically without any adverse effects on growing rabbit performance with percentages used.

Keywords: Nano zinc, nano copper, nano selenium, rabbits, growth performance, digestibility, carcass traits.

\section{INTRODUCTION}

Trace minerals have an important role in biological processes happened in animal body. Selenium (Se) is an essential trace mineral for animal and human. Supplementation of Se usually in livestock diet has been proved as effective element. The role of Se in production performance in animal seems to be dependent on both Se sources. Inorganic and organic forms of Se (selenate, selenide, seleniumenriched yeast, selenium-enriched algae) may be used as supplements. Selenate is the major inorganic selenocompound found in both animal and plant tissues (Guo and $\mathrm{Wu}, 1998$ ). Se supplementation may also improve the efficiency of the antioxidant system; enhance the disease resistance and nutritional quality of the livestock product. Zinc has an important role in numerous biological processes in avian and mammalian species. For instance, zinc and copper are an essential components of many enzymes (Vallee and Auld, 1990), and they have both structural and catalytic functions in metalloenzymes (O'Dell, 1992). Using trace minerals in a nano scale (between 1 nanometer (nm) and $100 \mathrm{~nm}$ ) maybe more active for a biological processes. The Nano-Cu used in dose $80 \mathrm{mg} / \mathrm{kg}$ in rabbit diet improved the activities of 
trypsin, amylase and lipase in the small intestinal contents and maltase, sucrose and lactase of duodenum, jejunum, and ileum mucosa (Xin-Yan Han, 2012). Many researches reported that a novel elemental Se source called Nano-Se possessed a higher efficiency than selenite, selenomethionine and methylselenocysteine in upregulating selenoenzymes in mice and rats (Zhang et al., 2005, 2008; Wang et al., 2007), and exhibited a lower toxicity (Zhang et al., 2001). The development of nanotechnology holds unique properties for this redox state Se 0, powder, because nanometer particulates exhibit novel characteristics, such as great specific surface area, high surface activity, a lot of surface active centers, high catalytic efficiency and strong adsorbing ability (Shi et al., 2011). However, little was known about influence of Nano-Cu, Nano-Zn and Nano-Se on animal nutrition. Thus, the objective of this study was to evaluate the effects of Nano-Cu, Nano-Zn and Nano-Se supplemented dose half in normal form in growing rabbit performance.

\section{MATERIALS AND METHODS}

This experimental study was carried out at Nobaria research Station, El-Behira Government, Egypt, Ministry of Agriculture. The Laboratory work was conducted at Laboratories of By-products Research Department, Animal Production Research Institute, Agricultural Research Center, Ministry of Agriculture, Egypt. The experiment aimed to evaluate adding copper, zinc and selenium in normal and nano form in even a half of amount in growing rabbit diets.

\section{Experimental diets}

Seven diets adding with Control (0), $1 \mathrm{~g}$ Normal copper $\mathrm{Cu}, 0.5 \mathrm{~g}$ Nano- $\mathrm{Cu}, 0.8$ Normal Zinc (Zn), $0.4 \mathrm{~g}$ Nano-Zn, 0.2 Normal selenium (Se) and $0.1 \mathrm{mg}$ Nano- Se/100kg diet, respectively. All diets were iso-protein and iso-digestible energy, and to satisfy the nutrient requirements according to Agriculture Ministry Decree (1996) recommendations. The experimental lasted for 8 weeks. Composition and calculated analysis of the experimental diets are presented in Table (1).

Nano trace minerals synthesized in National Research Centre, Center of Excellence for Advanced Sciences, Advanced Materials and Nanotechnology Group 12622 Dokki, Cairo, Egypt. Nano-Se was synthesized by reducing selenite in an environment containing bovine serum albumin (BSA), which is able to adhere to Se atoms and control the size of their aggregation according to Zhang et al. (2001). For nano copper and zinc were created by the artisans by adding copper and zinc salts and oxides together with vinegar, ochre and clay, on the surface of previously-glazed pottery. The object was then placed into a kiln and heated to about $600{ }^{\circ} \mathrm{C}$ in a reducing atmosphere. In the heat the glaze would soften, causing the copper and zinc ions to migrate into the outer layers of the glaze. There the reducing atmosphere reduced the ions back to metals, which then came together forming the nano particles according to Philip (1984).

To identify the particle size and morphology of the synthesized materials (Nano particles), transmission electron microscope (TEM) type "JEOL JEM-1230 operating at $120 \mathrm{kv}$ attached to a CCD camera" was used.

\section{Animals and management}

A total number of 84 NZW weaned rabbits at 5 weeks of age about $556 \mathrm{~g}$ as an average body weight were assigned, individually, into 7 treatments of 12 rabbits each. Rabbits were housed in galvanized metal rabbit battery cages $(60 \times 50 \times 40)$ supplied with separated feeders. Diets were offered in pellets form $a d$ libtum and fresh water was available all times from automatic nipple drinkers. All animals were kept under the same managements and hygienic conditions. Both feed intake and live body weight were recorded weekly and then feed conversion ratio was calculated

\section{Digestibility trail}

At the end of the experimental period, digestibility trail was carried out using four rabbits of each treatment. Feces were collected daily, weighed and dried at $60-70{ }^{\circ} \mathrm{C}$ for 24 hours, finely ground and stored for chemical analysis. Data of quantities and chemical analysis of feed and feces were used to calculate the nutrients digestion coefficients and the nutritive values of the dietary treatments, as described by Cheeke et al. (1982).

Blood samples were collected from three animals in each group, at the end of experimental period after slaughtering. Blood plasma samples were separated by centrifugation at $4000 \mathrm{rpm}$ for 10 minutes, 
then frozen at $-20^{0} \mathrm{C}$ until analysis. Commercial kits were used to determine plasma total protein, albumin, globulin and activities of AST and ALT, glucose, urea and total antioxidant capacity (TAC).

Table (1): Composition and calculated analysis of the experimental diets for growing rabbits.

\begin{tabular}{|c|c|c|c|c|c|c|c|}
\hline \multirow{3}{*}{ Ingredients } & \multirow[b]{3}{*}{$\begin{array}{l}\text { Control } \\
0 \%\end{array}$} & \multicolumn{2}{|c|}{ Copper** } & \multicolumn{2}{|c|}{ Zinc** } & \multicolumn{2}{|c|}{ Selenium** } \\
\hline & & normal & nano & normal & nano & normal & nano \\
\hline & & $\begin{array}{c}1 \mathrm{~g} / \\
100 \mathrm{~kg} \\
\end{array}$ & $\begin{array}{c}0.5 \mathrm{~g} / \\
100 \mathrm{~kg} \\
\end{array}$ & $\begin{array}{c}0.8 \mathrm{~g} / \\
100 \mathrm{~kg} \\
\end{array}$ & $\begin{array}{c}0.4 \mathrm{~g} / \\
100 \mathrm{~kg}\end{array}$ & $\begin{array}{c}0.2 \mathrm{mg} / \\
100 \mathrm{~kg}\end{array}$ & $\begin{array}{l}0.1 \mathrm{mg} / \\
100 \mathrm{~kg} \\
\end{array}$ \\
\hline Clover hay $(12 \% \mathrm{CP})$ & 30.00 & 30.00 & 30.00 & 30.00 & 30.00 & 30.00 & 30.00 \\
\hline Barely & 29.00 & 29.00 & 29.00 & 29.00 & 29.00 & 29.00 & 29.00 \\
\hline Yellow corn & 10.00 & 10.00 & 10.00 & 10.00 & 10.00 & 10.00 & 10.00 \\
\hline Soybean meal (44\%CP) & 18.00 & 18.00 & 18.00 & 18.00 & 18.00 & 18.00 & 18.00 \\
\hline Wheat bran & 8.00 & 8.00 & 8.00 & 8.00 & 8.00 & 8.00 & 8.00 \\
\hline Molasses & 3.00 & 3.00 & 3.00 & 3.00 & 3.00 & 3.00 & 3.00 \\
\hline DL-Methionine & 0.10 & 0.10 & 0.10 & 0.10 & 0.10 & 0.10 & 0.10 \\
\hline Vit..\& Min. mix. ${ }^{*}$ & 0.40 & 0.40 & 0.40 & 0.40 & 0.40 & 0.40 & 0.40 \\
\hline Salt & 0.50 & 0.50 & 0.50 & 0.50 & 0.50 & 0.50 & 0.50 \\
\hline Limestone & 1.00 & 1.00 & 1.00 & 1.00 & 1.00 & 1.00 & 1.00 \\
\hline Total & 100 & 100 & 100 & 100 & 100 & 100 & 100 \\
\hline \multicolumn{8}{|l|}{ Calculated analysis ${ }^{l}$} \\
\hline Crude protein $\%$ & 17.02 & 17.02 & 17.02 & 17.02 & 17.02 & 17.02 & 17.02 \\
\hline Digestible energy (Kcal/Kg) & 2500.0 & 2500.0 & 2500.0 & 2500.0 & 2500.0 & 2500.0 & 2500.0 \\
\hline $\mathrm{C} / \mathrm{P}$ ratio & 147 & 147 & 147 & 147 & 147 & 147 & 147 \\
\hline Ether extract \% & 2.72 & 2.72 & 2.72 & 2.72 & 2.72 & 2.72 & 2.72 \\
\hline Crude fiber \% & 13.25 & 13.25 & 13.25 & 13.25 & 13.25 & 13.25 & 13.25 \\
\hline $\mathrm{NDF} \%{ }^{\mathrm{m}}$ & 37.63 & 37.63 & 37.63 & 37.63 & 37.63 & 37.63 & 37.63 \\
\hline $\mathrm{ADF} \%^{\mathrm{n}}$ & 21.52 & 21.52 & 21.52 & 21.52 & 21.52 & 21.52 & 21.52 \\
\hline Hemicellulose $\%^{\circ}$ & 16.11 & 16.11 & 16.11 & 16.11 & 16.11 & 16.11 & 16.11 \\
\hline Calcium \% & 1.10 & 1.10 & 1.10 & 1.10 & 1.10 & 1.10 & 1.10 \\
\hline Total Phosphorus \% & 0.80 & 0.80 & 0.80 & 0.80 & 0.80 & 0.80 & 0.80 \\
\hline Methionine \% & 0.36 & 0.36 & 0.36 & 0.36 & 0.36 & 0.36 & 0.36 \\
\hline TSAA & 0.61 & 0.61 & 0.61 & 0.61 & 0.61 & 0.61 & 0.61 \\
\hline Lysine \% & 0.75 & 0.75 & 0.75 & 0.75 & 0.75 & 0.75 & 0.75 \\
\hline \multicolumn{8}{|c|}{ 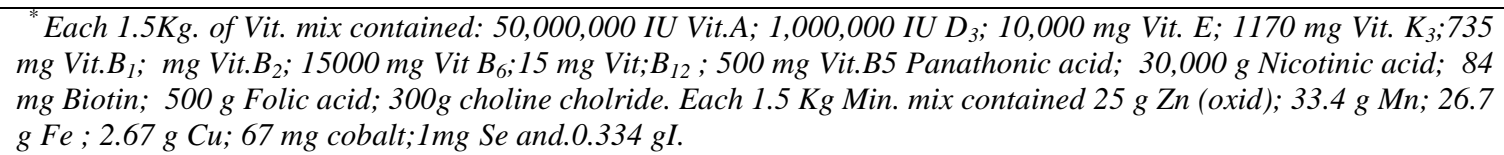 } \\
\hline \multicolumn{8}{|c|}{$\begin{array}{l}{ }^{l} \text { According to Feed Composition Tables for animal and poultry feedstuffs used in Egypt (2001), except values of } \\
\text { DDGS, which were determined (Table 2). }\end{array}$} \\
\hline \multicolumn{8}{|c|}{${ }^{\text {mno } \text { Calculated according to Cheeke (1987). }}$} \\
\hline \multicolumn{8}{|c|}{${ }^{m} \% N D F=28.924+0.657(\% C F)$} \\
\hline \multicolumn{8}{|l|}{${ }^{n} \% A D F=9.432+0.912(\% C F)$} \\
\hline \multicolumn{8}{|c|}{${ }^{o}$ Hemicellulose $=\% N D F-\% A D F$} \\
\hline
\end{tabular}

\section{Cecum activities}

Samples of cecum contents from the same slaughtered rabbits under each treatment were taken and used immediately for estimation of cecum $\mathrm{pH}$, cecum microflora (bacteria) Aerobic total count, Fecal coliforms, Escherichia coli count, Bacillus cereus, Enterobacter, Clostridium sp., Enterococcus, yeasts, Salmonella and Shigella. Another sample of cecum content was strained through four folds of gauze and divided into two portions. The first portion was used immediately for the estimation of ammonia nitrogen concentration. The second portion was preserved by addition of $1 \mathrm{ml} \mathrm{N} / 10 \mathrm{HCL}$ and $2 \mathrm{ml}$ orthophosphoric acid to each $2 \mathrm{ml}$ of cecum contents juice for determination total volatile fatty acids. The $\mathrm{pH}$ of the cecum contents was measured immediately by using a digital $\mathrm{pH}$ meter. The microbial contents 
were studied in their selective media, as described by Postage (1969) for Aerobic total bacterial counts and Difco (1989) for Fecal coliforms and E.coli, while, the methods described by Baired Parker (1962) and Kim and Goepfert (1971) were used for Enterococcus and Bacillus cereus, respectively and Difco (1989) for Enterobacter and Clostridium sp; while the method described by Lodder (1952) was used for yeasts determination. Salmonella and Shigella were enumerated according to the methods described by AOAC (1998). Technique of colony forming unit (CFU) was adopted. Incubation took place at $30{ }^{\circ} \mathrm{C}$ for 2-7 days. The ammonia nitrogen concentration was determined by applying method of Conway (1958). The total volatile fatty acids were determined by steam distillation of the distillate as mentioned by Eadie et al. (1967).

\section{Economic efficiency}

The economic efficiency of the experimental diets was calculated as the ratio between income (price of weight gain) and cost of feed consumed, calculated according to the price of the Egyptian market.

\section{Statistical analysis}

The data were analyzed using General Linear Models (GLM) procedure of SAS (2001). The statistical model was:

$\mathrm{Y}_{\mathrm{ij}}=\mu+\mathrm{T}_{\mathrm{i}}+\mathrm{e}_{\mathrm{ij}}$

Where: $\mu=$ overall mean of $\mathrm{Y}_{\mathrm{ij}}, \mathrm{T}_{\mathrm{i}}=$ Effect of treatment groups, $\mathrm{I}=(1, \ldots$ and 7$)$ and $\mathrm{e}_{\mathrm{ij}}=$ Experimental error. Variables having a significant F-test were compared using Duncan's multiple rang test (Duncan, 1955).

\section{RESULTS AND DISCUSSIN}

\section{Chemical structure of nano trace elements}

Images of synthesized copper (a), zinc (b), and selenium (c) nanoparticles at two different magnifications. It is indicated that the selenium exhibits agglomerated rod-like particles with homogeneous particles having length of about $50 \mathrm{~nm}$ and width ranging between 8 and $26 \mathrm{~nm}$. Welldispersed copper nano particles with different morphologies i.e. rods, cuboids and cubes, are appeared (Fig. 1c). Their sizes are ranging between $25-90 \mathrm{~nm}$. On the other hand, agglomerated flower shape zinc nanoparticles are detected (Fig. 1b). These agglomerates consist of several cube nanoparticles with size ranging between $6-11 \mathrm{~nm}$.

\section{Growth performance}

\section{Live body weight and body weight gain}

Results presented in Table (2) indicated that there is a significant $(\mathrm{P} \leq 0.05)$ difference between treatments comparing with control in final live body weight and body weight gain except that there isn't a significant difference between control group and group supplemented with Normal copper in a total body weight gain. The best one's were for group supplemented with nano-Se. Also, results indicated that no significant differences between groups supplemented with Nano- $\mathrm{Cu}$, Normal-Zn and Normal-Zn in alive body weight. in 9 weeks age, there no significant difference between group supplemented with $\mathrm{Nano}-\mathrm{Cu}$ and group supplemented with Nano-Se in alive body weight. For weight gain 10-13 weeks and a total weight gain there a significant difference between groups supplemented with Normal $\mathrm{Cu}, \mathrm{Zn}, \mathrm{Se}$ and group supplemented Nano form of them these results agree with Okunlola et al. (2015).

This result indicated that Nano form of trace element has more improving in live body weight and body weight gain, that's may be related to more active for a biological processes in body, which resulting to great specific surface area, high surface activity, a lot of surface active centers, high catalytic efficiency and strong adsorbing ability of elements in a Nano form (Zhang et al., 2005, 2008; Wang et al., 2007).

\section{Feed intake and feed conversion}

Also, results presented in Table (2) showed that a significant $(\mathrm{P} \leq 0.05)$ difference between control group and others groups that the higher one in total feed intake and feed conversion was in the control group. There is no significant difference in total feed intake and feed conversion between groups supplemented with Normal $\mathrm{Cu}, \mathrm{Zn}$, Se Nano $\mathrm{Cu}$ and $\mathrm{Zn}$. The best one in a total feed conversion was for group supplemented with Nano-Se. 
Results indicated that nano form of trace mineral groups were more improving in feed conversion that's relating to improving in weight gain in this groups. These results were in agreement with (Hu et al., 2012).
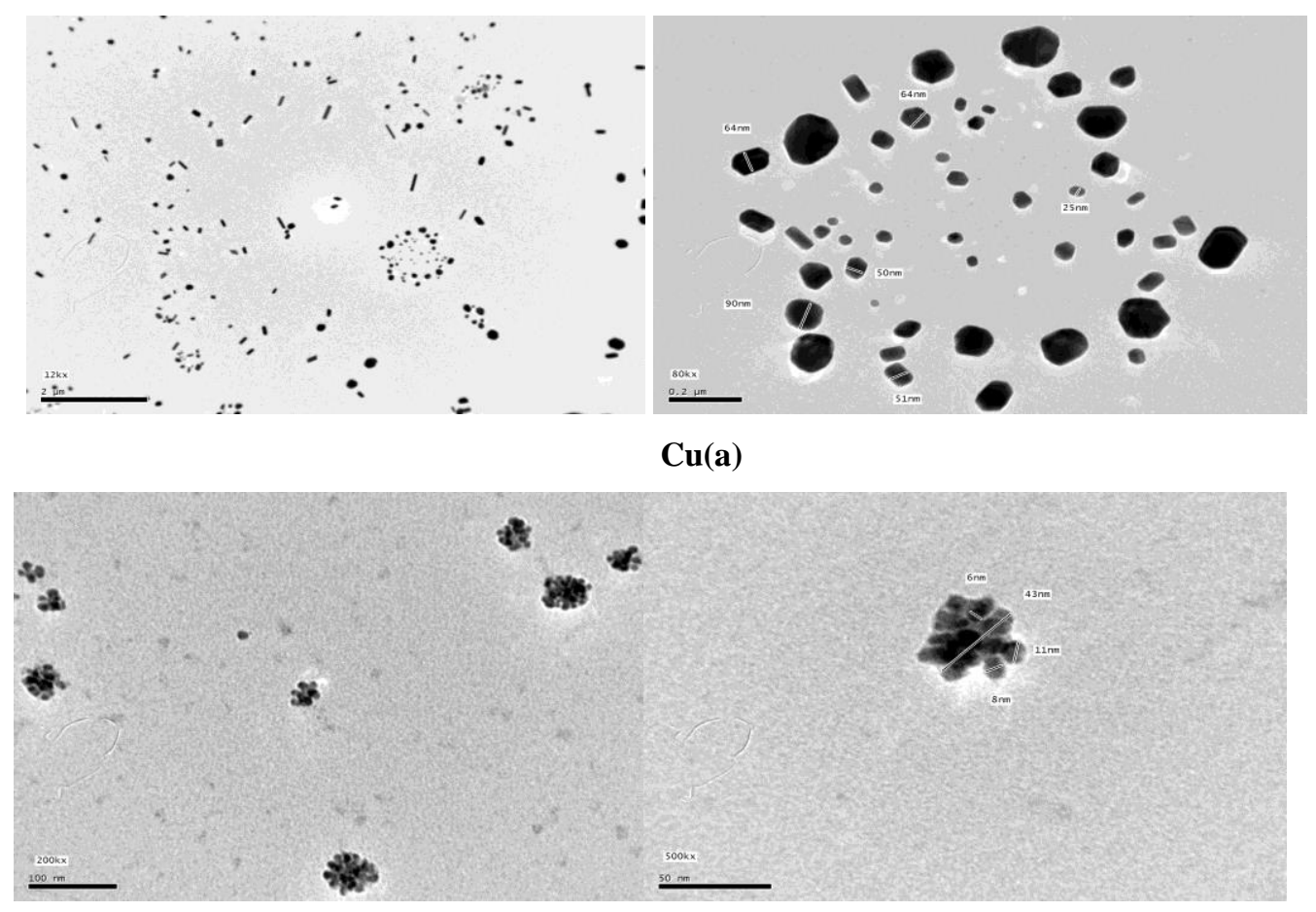

$\mathbf{Z n}(\mathbf{b})$

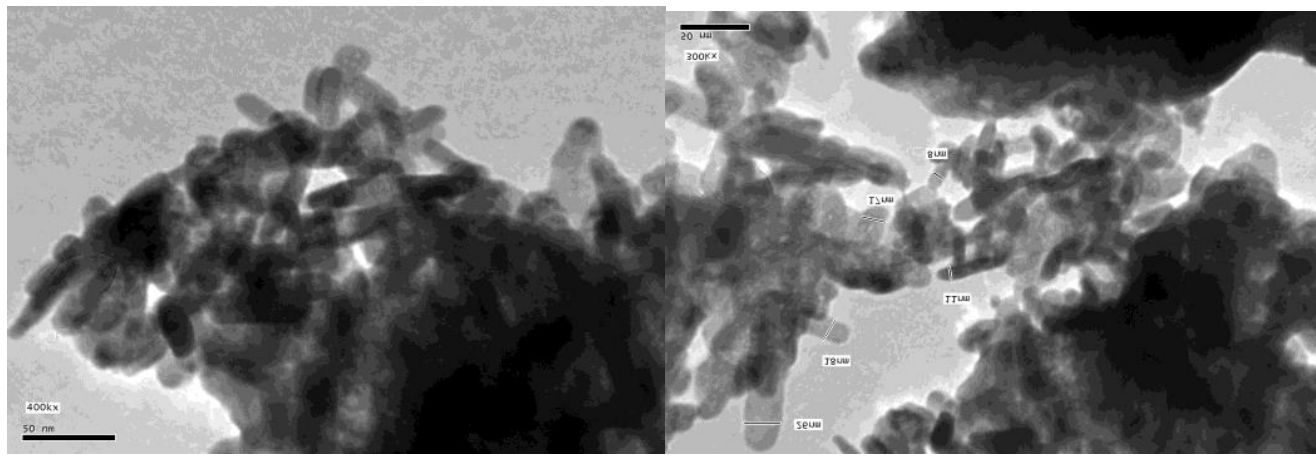

Se (c)

Figure (1): Images of synthesized copper (a), zinc (b) and selenium (c).

\section{Digestion coefficients of nutrients and nutritive values}

The results presented in Table (3) showed significant differences between groups in the most of the digestion coefficients of different nutrients and nutritive values. There is no significant difference in dry matter digestibility and organic matter digestibility only between groups. The digestion coefficients of different nutrients and nutritive values of diets contained trace minerals ( $\mathrm{Cu}, \mathrm{Zn}$ and Se) were significantly $(\mathrm{P} \leq 0.05)$ better than control group. Groups supplemented with Nano- $\mathrm{Cu}, \mathrm{Nano}-\mathrm{Ze}$ and Nano- Se were the best one's in the digestion coefficients of different nutrients and nutritive values between all groups. 
Abd-El Ghany et al.

Table (2): Rabbits performance values as affected by the experimental diets.

\begin{tabular}{|c|c|c|c|c|c|c|c|}
\hline Item & Control & $\begin{array}{l}\text { Normal } \\
\text { copper }\end{array}$ & $\begin{array}{l}\text { Nano } \\
\text { copper }\end{array}$ & $\begin{array}{l}\text { Normal } \\
\text { zinc }\end{array}$ & $\begin{array}{l}\text { Nano } \\
\text { zinc }\end{array}$ & $\begin{array}{c}\text { Normal } \\
\text { selenium }\end{array}$ & $\begin{array}{c}\text { Nano } \\
\text { selenium }\end{array}$ \\
\hline \multicolumn{8}{|c|}{ Live body weight $(g)$} \\
\hline Initial & 559.55 & 569.17 & 565.33 & 567.50 & 562.50 & 563.33 & 568.33 \\
\hline Weight & \pm 15.38 & \pm 18.98 & \pm 17.81 & \pm 16.79 & \pm 19.55 & \pm 20.28 & \pm 19.02 \\
\hline 9 weeks & $\begin{array}{c}1096.25^{\mathrm{d}} \\
\pm 26.34\end{array}$ & $\begin{array}{c}1153.75^{\mathrm{cd}} \\
\pm 26.34\end{array}$ & $\begin{array}{c}1248.33^{\mathrm{ab}} \\
\pm 21.81\end{array}$ & $\begin{array}{c}1217.08^{\mathrm{b}} \\
\pm 14.18\end{array}$ & $\begin{array}{c}1229.17^{\mathrm{b}} \\
\pm 24.97\end{array}$ & $\begin{array}{c}1196.25^{\mathrm{bcd}} \\
\pm 17.09\end{array}$ & $\begin{array}{c}1305.83^{\mathrm{a}} \\
\pm 15.40\end{array}$ \\
\hline 13 weeks & $\begin{array}{c}1693.42^{\mathrm{d}} \\
\pm 15.85\end{array}$ & $\begin{array}{r}1761.00^{\mathrm{c}} \\
\pm 18.12\end{array}$ & $\begin{array}{c}1806.67^{\mathrm{bc}} \\
\pm 21.19\end{array}$ & $\begin{array}{c}1785.00^{c} \\
\pm 23.31\end{array}$ & $\begin{array}{c}1845.00^{\mathrm{b}} \\
\pm 21.30\end{array}$ & $\begin{array}{r}1780.42^{\mathrm{c}} \\
\pm 11.94\end{array}$ & $\begin{array}{c}2.006 .67^{\mathrm{a}} \\
\pm 13.45\end{array}$ \\
\hline \multicolumn{8}{|c|}{ Body weight gain $(g)$} \\
\hline $5-9$ weeks & $\begin{array}{c}536.70^{\mathrm{e}} \\
\pm 18.47\end{array}$ & $\begin{array}{l}584.58^{\mathrm{d}} \\
\pm 14.61\end{array}$ & $\begin{array}{l}683.00^{\mathrm{b}} \\
\pm 21.71\end{array}$ & $\begin{array}{c}649.58^{\mathrm{bc}} \\
\pm 11.62\end{array}$ & $\begin{array}{c}666.67^{\mathrm{bc}} \\
\pm 15.19\end{array}$ & $\begin{array}{c}632.92^{\mathrm{c}} \\
\pm 8.23\end{array}$ & $\begin{array}{c}737.50^{\mathrm{a}} \\
\pm 9.70\end{array}$ \\
\hline 10-13weeks & $\begin{array}{c}597.17^{\mathrm{bc}} \\
\pm 17.50\end{array}$ & $\begin{array}{c}607.25^{\mathrm{bc}} \\
\pm 18.05\end{array}$ & $\begin{array}{l}558.34^{\mathrm{c}} \\
\pm 13.97\end{array}$ & $\begin{array}{c}567.92^{\mathrm{bc}} \\
\pm 14.45\end{array}$ & $\begin{array}{l}615.83^{\mathrm{b}} \\
\pm 10.11\end{array}$ & $\begin{array}{c}584.17^{\mathrm{bc}} \\
\pm 18.74\end{array}$ & $\begin{array}{l}700.84^{\mathrm{a}} \\
\pm 21.51\end{array}$ \\
\hline 5-13weeks & $\begin{array}{c}1133.87^{\mathrm{e}} \\
\pm 7.83\end{array}$ & $\begin{array}{c}1191.83^{\mathrm{de}} \\
\pm 18.92\end{array}$ & $\begin{array}{c}1241.34^{\mathrm{bc}} \\
\pm 19.44\end{array}$ & $\begin{array}{c}1217.50^{\mathrm{cd}} \\
\pm 19.51\end{array}$ & $\begin{array}{c}1282.50^{\mathrm{b}} \\
\pm 18.10\end{array}$ & $\begin{array}{c}1217.09^{\mathrm{cd}} \\
\pm 22.99\end{array}$ & $\begin{array}{c}1438.34^{\mathrm{a}} \\
\pm 26.02\end{array}$ \\
\hline \multicolumn{8}{|l|}{ Feed intake $(g)$} \\
\hline 5-9 weeks & $\begin{array}{c}1721.50^{\mathrm{ab}} \\
\pm 62.10\end{array}$ & $\begin{array}{c}1503.50^{\mathrm{c}} \\
\pm 42.25\end{array}$ & $\begin{array}{c}1681.58^{\mathrm{ab}} \\
\pm 62.35\end{array}$ & $\begin{array}{c}1570.25^{\mathrm{bc}} \\
\pm 22.36\end{array}$ & $\begin{array}{c}1619.00^{\mathrm{bc}} \\
\pm 46.55\end{array}$ & $\begin{array}{c}1598.33^{\mathrm{bc}} \\
\pm 56.30\end{array}$ & $\begin{array}{c}1803.92^{\mathrm{a}} \\
\pm 47.60\end{array}$ \\
\hline $10-13$ weeks & $\begin{array}{c}2737.50^{\mathrm{a}} \\
\pm 89.99\end{array}$ & $\begin{array}{c}2195.20^{\mathrm{bc}} \\
\pm 103.48\end{array}$ & $\begin{array}{c}2093.10^{\mathrm{c}} \\
\pm 53.46\end{array}$ & $\begin{array}{c}2150.90^{\mathrm{bc}} \\
\pm 57.31\end{array}$ & $\begin{array}{c}2337.90^{\mathrm{b}} \\
\pm 53.83\end{array}$ & $\begin{array}{c}2224.80^{\mathrm{bc}} \\
. \pm 91.26\end{array}$ & $\begin{array}{c}2178.50^{\mathrm{bc}} \\
\pm 49.15\end{array}$ \\
\hline 5-13weeks & $\begin{array}{c}4459.00^{\mathrm{a}} \\
\pm 67.34\end{array}$ & $\begin{array}{c}3698.70^{\mathrm{d}} \\
\pm 88.54\end{array}$ & $\begin{array}{c}3374.68^{\mathrm{bcd}} \\
\pm 62.73\end{array}$ & $\begin{array}{c}3721.15^{\mathrm{cd}} \\
\pm 70.29\end{array}$ & $\begin{array}{c}3956.90^{\mathrm{bc}} \\
\pm 63.61\end{array}$ & $\begin{array}{c}3823.13^{\mathrm{bcd}} \\
\pm 116.10\end{array}$ & $\begin{array}{c}3982.42^{\mathrm{b}} \\
\pm 67.46\end{array}$ \\
\hline \multicolumn{8}{|l|}{ Feed conversion } \\
\hline 5-9 weeks & $\begin{array}{l}3.21^{\mathrm{a}} \\
\pm 0.08\end{array}$ & $\begin{array}{l}2.57^{\mathrm{b}} \\
\pm 0.07\end{array}$ & $\begin{array}{l}2.46^{\mathrm{b}} \\
\pm 0.07\end{array}$ & $\begin{array}{l}2.42^{b} \\
\pm 0.03\end{array}$ & $\begin{array}{l}2.43^{b} \\
\pm 0.03\end{array}$ & $\begin{array}{l}2.53^{\mathrm{b}} \\
\pm 0.08\end{array}$ & $\begin{array}{l}2.45^{b} \\
\pm 0.05\end{array}$ \\
\hline $10-13$ weeks & $\begin{array}{l}4.58^{\mathrm{a}} \\
\pm 0.06\end{array}$ & $\begin{array}{l}3.61^{\mathrm{b}} \\
\pm 0.11\end{array}$ & $\begin{array}{l}3.75^{\mathrm{b}} \\
\pm 0.08\end{array}$ & $\begin{array}{l}3.79^{\mathrm{b}} \\
\pm 0.07\end{array}$ & $\begin{array}{l}3.80^{\mathrm{b}} \\
\pm 0.03\end{array}$ & $\begin{array}{l}3.81^{\mathrm{b}} \\
\pm 0.08\end{array}$ & $\begin{array}{l}3.11^{\mathrm{c}} \\
\pm 0.04\end{array}$ \\
\hline 5-13weeks & $\begin{array}{l}3.93^{\mathrm{a}} \\
\pm 0.06\end{array}$ & $\begin{array}{l}3.10^{\mathrm{b}} \\
\pm 0.04\end{array}$ & $\begin{array}{l}3.04^{\mathrm{b}} \\
\pm 0.04\end{array}$ & $\begin{array}{l}3.06^{\mathrm{b}} \\
\pm 0.03\end{array}$ & $\begin{array}{l}3.09^{\mathrm{b}} \\
\pm 0.01\end{array}$ & $\begin{array}{l}3.14^{\mathrm{b}} \\
\pm 0.04\end{array}$ & $\begin{array}{l}2.77^{\mathrm{c}} \\
\pm 0.03\end{array}$ \\
\hline
\end{tabular}

$a, b, c, d$ and $e:$ Means in the same row with different superscripts are significantly different $(P \leq 0.05)$.

$S E=$ Standard error .

Table (3): Digestion coefficients of nutrients and nutritive values as affected by the experimental diets.

\begin{tabular}{lcccccccc}
\hline \multirow{2}{*}{ Treatments } & \multicolumn{9}{c}{ Digestibility $(\%)$} & \multicolumn{3}{c}{ Nutritive values $^{\mathrm{k}}$} \\
\cline { 2 - 10 } & DM & OM & CP & CF & EE & NFE & TDN & DCP \\
\hline Control & 64.53 & 59.21 & $71.68^{\mathrm{c}}$ & $46.57^{\mathrm{c}}$ & $77.65^{\mathrm{b}}$ & $67.61^{\mathrm{b}}$ & $52.36^{\mathrm{b}}$ & $13.56^{\mathrm{c}}$ \\
& \pm 0.96 & \pm 2.19 & \pm 0.19 & \pm 0.99 & \pm 1.29 & \pm 1.63 & \pm 1.68 & \pm 0.04 \\
Normal & 64.55 & 64.55 & $76.03^{\mathrm{b}}$ & $55.11^{\mathrm{ab}}$ & $82.22^{\mathrm{a}}$ & $70.31^{\mathrm{b}}$ & $60.10^{\mathrm{b}}$ & $14.41^{\mathrm{b}}$ \\
Copper & \pm 0.53 & \pm 0.48 & $\pm 0.68^{\mathrm{b}}$ & $\pm 1.48^{\mathrm{a}}$ & \pm 1.71 & \pm 1.96 & $\pm 1.42^{\mathrm{a}}$ & \pm 0.13 \\
Nano & 64.57 & 59.86 & $75.01^{\mathrm{b}}$ & $55.54^{\mathrm{ab}}$ & $82.81^{\mathrm{a}}$ & $68.70^{\mathrm{b}}$ & $57.38^{\mathrm{b}}$ & $14.20^{\mathrm{b}}$ \\
Copper & \pm 0.34 & \pm 0.80 & \pm 0.89 & \pm 1.18 & \pm 0.59 & \pm 0.55 & \pm 1.13 & \pm 0.17 \\
Normal & 64.18 & 59.70 & $75.76^{\mathrm{b}}$ & $52.73^{\mathrm{b}}$ & $82.33^{\mathrm{a}}$ & $68.27^{\mathrm{b}}$ & $57.42^{\mathrm{b}}$ & $14.32^{\mathrm{b}}$ \\
Zinc & \pm 1.64 & \pm 2.37 & \pm 1.51 & \pm 2.43 & \pm 1.28 & \pm 2.76 & \pm 2.53 & \pm 0.29 \\
Nano & 64.95 & 60.74 & $75.26^{\mathrm{b}}$ & $55.30^{\mathrm{ab}}$ & $83.27^{\mathrm{a}}$ & $69.03^{\mathrm{b}}$ & $58.02^{\mathrm{b}}$ & $14.28^{\mathrm{b}}$ \\
Zinc & \pm 1.21 & $\pm 1,28$ & $\pm 1.18^{\mathrm{b}}$ & \pm 2.49 & \pm 0.55 & \pm 0.37 & \pm 1.23 & \pm 0.23 \\
Normal & 62.44 & 57.78 & $75.22^{\mathrm{b}}$ & $50.02^{\mathrm{bc}}$ & $76.96^{\mathrm{b}}$ & $67.35^{\mathrm{b}}$ & $56.53^{\mathrm{bc}}$ & $14.20^{\mathrm{b}}$ \\
Selenium & \pm 0.19 & \pm 0.49 & \pm 0.15 & \pm 0.49 & \pm 0.67 & \pm 0.70 & \pm 0.60 & \pm 0.03 \\
Nano & 64.36 & 62.37 & $79.53^{\mathrm{a}}$ & $59.74^{\mathrm{a}}$ & $85.59^{\mathrm{a}}$ & $76.76^{\mathrm{b}}$ & $64.62^{\mathrm{a}}$ & $15.15^{\mathrm{a}}$ \\
Selenium & \pm 1.11 & \pm 4.99 & \pm 0.87 & \pm 2.22 & \pm 0.24 & \pm 0.16 & \pm 0.60 & \pm 0.16 \\
\hline
\end{tabular}

$a, b$ and $c$ : Means in the same column with different superscripts are significantly different $(P \leq 0.05)$.

: Calculated according to Cheeke et al. (1982). 
Results indicated that nano form of trace minerals were more improving the digestion coefficients of different nutrients and nutritive values, that's may be related to more active for a biological processes and great specific surface area, high surface activity and strong adsorbing ability of elements in a nano form (Zhang et al., 2005, 2008 and Wang et al., 2007). That's improving soluble fiber has high water holding capacity, readily forms gel, increases luminal viscosity, and is easily degraded by micro- flora in the large bowel. On the contrarily, insoluble fiber has little water holding capacity, decreases transit time, is only partially degraded by micro- flora, and increases fecal bulk (Swanson et al., 2001).

Also, results agree with Shi et al. (2011) who indicated that fraction of CP was quadratically $(\mathrm{P}<0.01)$ increased with increasing Nano-Se supplementation and Xin-Yan Han (2012) who reported that the Nano-Cu used in dose $80 \mathrm{mg} / \mathrm{kg}$ in rabbit diet improved the activities of trypsin, amylase and lipase in the small intestinal contents and maltase, sucrose and lactase of duodenum, jejunum, and ileum mucosa.

\section{Carcass traits}

Effects of diets on carcass traits are shown in Table (4). Diets had significant $(\mathrm{P} \leq 0.05)$ effect on carcass traits, with no clear trend. Highest cecum weight and total edible parts were in group supplemented with Nano-Se. Also, the highest liver and heart weight were in group supplemented with Nano-Se. These results were in agreement with (Hu et al., 2012). There is no significant $(\mathrm{P} \geq 0.05)$ difference in dressing percentage between control group and groups supplemented with normal and Nano$\mathrm{Zn}$ and the lower one significantly $(\mathrm{P} \leq 0.05)$ was for group supplemented with normal $\mathrm{Cu}$. The highest group significantly $(\mathrm{P} \leq 0.05)$ in edible parts percentage was for group supplemented with Nano-Se. These results agree with (Selim et al., 2015) who reported that using Se-Yeast or Zn-Se Methionine as organic form of Se or L-Nano Se as nano form of Se at level of $0.30 \mathrm{ppm}$ in broiler diets or its equivalent in drinking water are more effective to get better growth performance and quality of broiler meat.

\section{Blood parameters}

Table (5) showed the effect of feeding rabbits on different diets on plasma constituents. There are significant effects on all parameters measured, except AST with no trend. Also, the Table showed that rabbit feeding on diet supplemented with Nano-Se increased significantly $(\mathrm{P}<0.05)$ in total protein, glucose and total antioxidant capacity. These results agree with Okunlola et al. (2015), who indicated that the activity of the blood enzymes measured increase with selenium supplementation whereas the cholesterol fall significantly in birds fed selenium supplemented diets. The heamatological and serum characteristics were not significantly affected $(\mathrm{P} \geq 0.05)$ across the treatments, except the differential count of the white blood cells.

\section{Cecum activities}

Data in Table (6) showed the effect of using different forms of $\mathrm{Cu}, \mathrm{Zn}$ and $\mathrm{Se}$ in rabbit diets on cecum activity $\mathrm{pH}$, ammonia and TVFA's which were determined, at the end of the growing period (13 weeks of age), the results showed that had significant $(\mathrm{P} \leq 0.05)$ effect on cecum $\mathrm{pH}$, ammonia and TVFA's concentration. The values of $\mathrm{pH}$ were ranged between $6.10-6.23$ for treatments groups vs. 6.07 for control, while ammonia concentration values ranged between $7.83-8.98 \mathrm{mg} / 100 \mathrm{ml}$ for treatments vs. $8.99 \mathrm{mg} / 100 \mathrm{ml}$ for control. Ammonia concentration decreased in rabbits fed on diets supplemented with trace elements, especially diets supplemented with Nano-Zn and Nano-Se. All rabbits fed on diets gave higher cecum $\mathrm{pH}$ than the control. The lowest $(\mathrm{P} \leq 0.05)$ values of ammonia concentration were for Nano-Se. Results indicated that had significant effect on total volatile fatty acids (TVFA) values of cecum. However, TVFA's ranged between $9.49-10.35$ (ml eq/100ml) for treatments groups vs. 9.24 for control. The previous results may be due to treatments that yeast counts increased in diets supplemented with trace minerals when compared with the control that's agree with Lansdown (2006), that may be the reason of decreasing ammonia concentration and increased values of $\mathrm{pH}$ and TVFA's .

Cecum microbial counts $\left(\log ^{-1} \mathrm{CFU} / \mathrm{ml}\right)$ as affected by experimental diets were presented in Table (7). Results showed that lowest cecum microbial counts were noticed with Nano-Se group. Yeast counts increased when compared with the control diet, except with normal-Cu group. These results may be due to antimicrobial effect of nano form element for harmful micro-organisms Lansdown (2006). 
Abd-El Ghany et al.

Table (4): Carcass traits of rabbits as affected by the experimental diets.

\begin{tabular}{|c|c|c|c|c|c|c|c|c|}
\hline \multirow[t]{3}{*}{ Treatments } & \multicolumn{8}{|c|}{ Carcass traits } \\
\hline & \multicolumn{2}{|c|}{ Empty Carcass } & Liver & \multirow{2}{*}{$\begin{array}{c}\text { Kidney } \\
\%\end{array}$} & \multirow{2}{*}{$\begin{array}{c}\text { Heart } \\
\%\end{array}$} & \multirow{2}{*}{$\begin{array}{c}\text { ceacum } \\
\text { weight }\end{array}$} & \multirow{2}{*}{$\begin{array}{c}\text { Dressing } \\
\%\end{array}$} & \multirow{2}{*}{$\begin{array}{c}\text { Edible giblets } \\
\%\end{array}$} \\
\hline & weight & $\%$ & $\%$ & & & & & \\
\hline Control & $119.33 \pm 14.53^{\mathrm{a}}$ & $68.62 \pm 1.58^{\mathrm{a}}$ & $2.80 \pm 0.14^{\mathrm{bc}}$ & $0.82 \pm 0.01^{\mathrm{ab}}$ & $0.25 \pm 0.02^{\mathrm{c}}$ & $90.67 \pm 1.76^{b}$ & $68.62 \pm 1.58^{\mathrm{a}}$ & $3.87 \pm 0.17^{\mathrm{cd}}$ \\
\hline Normal Cupper & $1056.67 \pm 23.33^{\mathrm{b}}$ & $59.72 \pm 1.47^{\mathrm{c}}$ & $2.92 \pm 0.07^{\mathrm{b}}$ & $0.86 \pm 0.01^{\mathrm{a}}$ & $0.29 \pm 0.002^{\mathrm{ab}}$ & $89.33 \pm 2.85^{b}$ & $59.72 \pm 1.47^{\mathrm{c}}$ & $4.07 \pm 0.06^{\mathrm{bc}}$ \\
\hline Nano Cupper & $1163.33 \pm 17.64^{\mathrm{a}}$ & $62.58 \pm 1.41^{\mathrm{bc}}$ & $2.58 \pm 0.09^{\mathrm{cd}}$ & $0.78 \pm 0.02^{\mathrm{cd}}$ & $0.27 \pm 0.004^{b c}$ & $86.67 \pm 4.26^{\mathrm{b}}$ & $62.58 \pm 1.41^{\mathrm{bc}}$ & $3.63 \pm 0.11^{\text {de }}$ \\
\hline Normal Zinc & $1170.00 \pm 41.63^{\mathrm{a}}$ & $66.35 \pm 2.21^{\mathrm{ab}}$ & $2.65 \pm 0.08^{\mathrm{bcd}}$ & $0.83 \pm 0.01^{\mathrm{ab}}$ & $0.29 \pm 0.01^{\mathrm{abc}}$ & $90.10 \pm 5.08^{\mathrm{b}}$ & $66.35 \pm 2.21^{\mathrm{ab}}$ & $3.76 \pm 0.09^{\text {cde }}$ \\
\hline Nano Zinc & $1206.67 \pm 39.30^{a}$ & $64.36 \pm 2.82^{\mathrm{abc}}$ & $2.42 \pm 0.07^{\mathrm{d}}$ & $0.79 \pm 0.002^{\mathrm{bcd}}$ & $0.26 \pm 0.002^{\mathrm{bc}}$ & $92.00 \pm 1.53^{\mathrm{b}}$ & $64.36 \pm 2.82^{\mathrm{abc}}$ & $3.47 \pm 0.07^{\text {cde }}$ \\
\hline Normal Selenium & $1070.00 \pm 32.15^{\mathrm{b}}$ & $58.88 \pm 0.83^{\mathrm{c}}$ & $3.21 \pm 0.01^{\mathrm{a}}$ & $0.82 \pm 0.01^{\mathrm{bc}}$ & $0.32 \pm 0.02^{\mathrm{a}}$ & $95.83 \pm 2.09^{\mathrm{ab}}$ & $58.88 \pm 0.83^{\mathrm{c}}$ & $4.35 \pm 0.03^{\mathrm{ab}}$ \\
\hline Nano Selenium & $1243.33 \pm 29.06^{\mathrm{a}}$ & $61.54 .1 .09^{b c}$ & $3.45 \pm 0.12^{\mathrm{a}}$ & $0.77 \pm 0.1^{\mathrm{d}}$ & $0.31 \pm 0.007^{\mathrm{a}}$ & $103.67 \pm 3.48^{\mathrm{a}}$ & $61.54 \pm 1.09^{\mathrm{bc}}$ & $4.53 \pm 0.13^{\mathrm{a}}$ \\
\hline
\end{tabular}

Total edible parts $w t .=$ Dressing $w t .=$ Empty carcass $w t .($ without head $)+$ Edible giblets $w t$.

Edible giblets $w t .=$ Liver $w t .+$ Kidney $w t .+$ Heart $w t$.

Total edible parts $\%=$ Total edible parts $w$ t. $/$ fasted $w t . * 100$. 
Table (5). Some blood plasma parameters of rabbits as affected by the experimental diets.

\begin{tabular}{|c|c|c|c|c|c|c|c|c|c|}
\hline \multirow[t]{3}{*}{ Treatments } & \multicolumn{9}{|c|}{ Blood plasma parameters } \\
\hline & Glucose & Total protein & Albumin & Globulin & $\mathrm{A} / \mathrm{G}$ & ALT & AST & Urea & $\mathrm{TAC}^{*}$ \\
\hline & $(\mathrm{g} / \mathrm{dl})$ & $(\mathrm{g} / \mathrm{dl})$ & $(\mathrm{g} / \mathrm{dl})$ & $(\mathrm{g} / \mathrm{dl})$ & ratio & $(\mathrm{U} / \mathrm{I})$ & $(\mathrm{U} / \mathrm{I})$ & (mg/dl) & (g/dl) \\
\hline Control & $55.00 \pm 2.89^{\mathrm{b}}$ & $6.03 \pm 0.23^{\mathrm{c}}$ & $3.79 \pm 0.23^{\mathrm{c}}$ & $2.24 \pm 0.42^{\mathrm{bc}}$ & $1.83 \pm 0.37^{\mathrm{bc}}$ & $24.76 \pm 3.96^{\mathrm{cd}}$ & $57.14 \pm 3.30$ & $93.33 \pm 7.70^{\mathrm{a}}$ & $2.90 \pm 0.08^{\mathrm{d}}$ \\
\hline Normal Cupper & $75.00 \pm 1.44^{\mathrm{b}}$ & $6.45 \pm 0.05^{\mathrm{c}}$ & $4.11 \pm 0.37^{\mathrm{bc}}$ & $2.35 \pm 0.34^{\mathrm{bc}}$ & $1.88 \pm 0.46^{\mathrm{bc}}$ & $45.71 \pm 1.10^{\mathrm{a}}$ & $85.71 \pm 16.50$ & $88.56 \pm 9.28^{\mathrm{a}}$ & $3.97 \pm 0.03^{\mathrm{a}}$ \\
\hline Nano Cupper & $65.00 \pm 4.33^{\mathrm{b}}$ & $7.91 \pm 0.26^{\mathrm{ab}}$ & $6.40 \pm 0.28^{\mathrm{a}}$ & $1.51 \pm 0.01^{\mathrm{c}}$ & $4.25 \pm 0.23^{\mathrm{a}}$ & $43.81 \pm 3.30^{\mathrm{a}}$ & $80.00 \pm 6.60$ & $32.63 \pm 3.91^{\mathrm{b}}$ & $3.33 \pm 0.35^{\mathrm{c}}$ \\
\hline Normal Zinc & $105.78 \pm 5.04^{\mathrm{a}}$ & $6.24 \pm 0.13^{\mathrm{c}}$ & $4.80 \pm 0.09^{b}$ & $1.44 \pm 0.13^{\mathrm{c}}$ & $3.39 \pm 0.34^{\mathrm{ab}}$ & $27.94 \pm 1.68^{\mathrm{bc}}$ & $66.67 \pm 5.04$ & $80.00 \pm 6.93^{\mathrm{a}}$ & $3.57 \pm 0.24^{\mathrm{abc}}$ \\
\hline Nano Zinc & $127.17 \pm 10.74^{\mathrm{a}}$ & $6.88 \pm 0.58^{\mathrm{bc}}$ & $4.89 \pm 0.39^{\mathrm{b}}$ & $1.99 \pm 0.73^{\mathrm{c}}$ & $3.26 \pm 1.13^{\mathrm{ab}}$ & $19.05 \pm 1.10^{\mathrm{d}}$ & $51.42 \pm 3.30$ & $42.26 \pm 12.36^{\mathrm{b}}$ & $3.36 \pm 0.12^{\mathrm{bc}}$ \\
\hline Normal Selenium & $106.33 \pm 11.05^{\mathrm{a}}$ & $7.94 \pm 0.23^{\mathrm{ab}}$ & $4.48 \pm 0.09^{\mathrm{bc}}$ & $3.46 \pm 0.14^{\mathrm{ab}}$ & $1.30 \pm 0.03^{\mathrm{c}}$ & $32.77 \pm 1.39^{\mathrm{b}}$ & $68.45 \pm 9.41$ & $29.69 \pm 1.99^{\mathrm{b}}$ & $3.91 \pm 0.04^{\mathrm{ab}}$ \\
\hline Nano Selenium & $122.33 \pm 6.49^{\mathrm{a}}$ & $8.52 \pm 0.95^{\mathrm{a}}$ & $4.71 \pm 0.45^{\mathrm{bc}}$ & $3.80 \pm 0.52^{\mathrm{a}}$ & $1.26 \pm 0.07^{\mathrm{c}}$ & $25.40 \pm 1.68^{\mathrm{cd}}$ & $93.33 \pm 18.67$ & $34.56 \pm 4.43^{b}$ & $3.89 \pm 0.07^{\mathrm{abc}}$ \\
\hline
\end{tabular}

$a, b, c$ and $d$ : Means in the same column with different superscripts are significantly different $(p \leq 0.05)$

$* T A C=$ total antioxidant capacity. 


\section{Economic efficiency}

Results in Table (8) showed that the least feed cost/ Kg body weight gain, economic efficiency and the best relative economic efficiency were recorded for Nano-Cu supplementation, while the worst values were for control, but the all diets for normal and nano trace elements were better than the control diet. These results were in agreement with (Hu et al., 2012) who reported that using selenium in nano form was more economically than control.

Conclusively, adding copper, zinc and selenium in normal form and nano form in even a half of amount in growing rabbit diets can be used economically without any adverse effects on growing rabbit performance.

Table (6): Cecum activity of rabbits as affected by the experimental diets.

\begin{tabular}{lccc}
\hline Treatments & \multicolumn{3}{c}{ Cecum activity } \\
\cline { 2 - 4 } & $\mathrm{pH}$ & Ammonia $(\mathrm{mg} / 100 \mathrm{ml})$ & TVFA's $(\mathrm{ml} \mathrm{eq} / 100 \mathrm{ml})$ \\
\hline Control & $6.07^{\mathrm{c}} \pm 0.03$ & $8.99^{\mathrm{a}} \pm 0.13$ & $9.24^{\mathrm{d}} \pm 0.07$ \\
Normal -Copper & $6.22^{\mathrm{ab}} \pm 0.01$ & $8.58^{\mathrm{b}} \pm 0.06$ & $9.49^{\mathrm{cd}} \pm 0.16$ \\
Nano- Copper & $6.10^{\mathrm{c}} \pm 0.04$ & $8.20^{\mathrm{cd}} \pm 0.10$ & $9.65^{\mathrm{bcd}} \pm 0.08$ \\
Normal-Zinc & $6.23^{\mathrm{a}} \pm 0.02$ & $8.45^{\mathrm{b}} \pm 0.04$ & $9.95^{\mathrm{abc}} \pm 0.06$ \\
Nano-Zinc & $6.12^{\mathrm{bc}} \pm 0.04$ & $7.83^{\mathrm{e}} \pm 0.03$ & $10.35^{\mathrm{a}} \pm 0.23$ \\
Normal-Selenium & $6.23^{\mathrm{a}} \pm 0.03$ & $8.35^{\mathrm{bc}} \pm 0.07$ & $10.01^{\mathrm{ab}} \pm 0.22$ \\
Nano-Selenium & $6.15^{\mathrm{abc}} \pm 0.03$ & $7.98^{\mathrm{de}} \pm 0.08$ & $10.18^{\mathrm{a}} \pm 0.16$ \\
\hline
\end{tabular}

$a, b, c, d$ and $e:$ Means on the same column with different superscripts are significantly different $(P \leq 0.05)$.

\pm : Standard error

Table (7): Microbial counts $\left(\log ^{-1} \mathrm{CFU} / \mathrm{ml}\right)$ as affected by the experimental diets.

\begin{tabular}{lcccccccc}
\hline $\begin{array}{l}\text { Cecum microbos } \\
(\text { CFU/ml) }\end{array}$ & Control & $\begin{array}{c}\text { Normal } \\
\text { Copper }\end{array}$ & $\begin{array}{c}\text { Nano } \\
\text { Copper }\end{array}$ & $\begin{array}{c}\text { Normal } \\
\text { Zinc }\end{array}$ & $\begin{array}{c}\text { Nano } \\
\text { Zinc }\end{array}$ & $\begin{array}{c}\text { Normal } \\
\text { Selenium }\end{array}$ & $\begin{array}{c}\text { Nano } \\
\text { Selenium }\end{array}$ & $\begin{array}{c}\text { LSD } \\
(0.05)\end{array}$ \\
\hline Aerobic total count & 7.081 & 5.375 & 5.028 & 6.786 & 6.380 & 5.982 & 4.804 & 1.752 \\
Fecal coliforms & 6.105 & 3.657 & 3.070 & 4.720 & 4.634 & 4.873 & 4.883 & 1.389 \\
E.Coli & 7.298 & 3.657 & 4.565 & 2.363 & 4.820 & 2.546 & 6.435 & 1.433 \\
Bacillus cereus & 4.450 & 4.984 & 6.016 & 4.752 & 4.583 & 3.212 & 4.735 & 1.229 \\
Enterobacter & 5.696 & 4.183 & 3.293 & 3.028 & 4.930 & 3.235 & 3.720 & 1.344 \\
Clostridium sp & 2.314 & 1.993 & 1.637 & 1.940 & 1.851 & 1.734 & 2.064 & 1.746 \\
Enterococcus & 4.058 & 3.996 & 3.738 & 3.764 & 3.435 & 2.341 & 3.720 & 1.500 \\
Yeasts & 5.028 & 4.930 & 5.105 & 5.776 & 6.586 & 6.745 & 6.194 & 1.390 \\
Salmonella \& Shigella & ND & ND & ND & ND & ND & ND & ND & - \\
\hline
\end{tabular}

Each value is an average of 3 observations.

LSD between treatments d.f (0.05).

$N D=$ Not detected

Number of bacterial cells per gram of cecum content $\left(\log 10^{-1} \mathrm{CFU} / \mathrm{ml}\right)$.

${ }^{l} \mathrm{CFU}$ (Colony forming unite) 
Table (8): Economical efficiency of experimental diets for growing rabbits as affected by different treatments.

\begin{tabular}{|c|c|c|c|c|c|c|c|}
\hline \multirow[t]{2}{*}{ Item } & \multicolumn{7}{|c|}{ Weeks (5-13) } \\
\hline & Control & Normal Copper & Nano Copper & Normal Zinc & Nano Zinc & Normal Selenium & Nano Selenium \\
\hline Price / kg diet (pt) & 265.00 & 265.95 & 266.44 & 265.80 & 266.20 & 265.25 & 265.84 \\
\hline Total feed intake/rabbit (gm) & 4459.00 & 3698.70 & 3374.68 & 3721.15 & 3956.90 & 3823.13 & 3982.42 \\
\hline Total feed cost/rabbit (LE) & 9.85 & 8.21 & 7.49 & 8.24 & 8.78 & 8.45 & 8.82 \\
\hline Total weight gain/rabbit(gm) & 1133.87 & 1191.83 & 1241.34 & 1217.50 & 1282.50 & 1217.09 & 1438.34 \\
\hline Feed cost / kg gain & 8.69 & 6.89 & 6.03 & 6.77 & 6.85 & 6.94 & 6.13 \\
\hline Total revenue/rabbit (LE) & 19.28 & 20.26 & 21.10 & 20.70 & 21.80 & 20.69 & 24.45 \\
\hline Net revenue/rabbit (LE) & 9.43 & 12.05 & 13.61 & 12.46 & 13.02 & 12.24 & 15.63 \\
\hline Economical efficiency(EE) & 0.96 & 1.47 & 1.82 & 1.51 & 1.48 & 1.45 & 1.77 \\
\hline Relative EE\% & 100 & 153.13 & 189.58 & 157.26 & 154.17 & 151.04 & 184.38 \\
\hline
\end{tabular}

Based on prices of the Egyptian market during the experimental period (2016). Initial price of rabbit 17 LE.

Net revenue $/$ rabbit $(L E)=($ Total revenue $/$ rabbit $(L E))-($ Total feed cost $/$ rabbit $(L E))$.

Economical efficiency $=($ Net revenue/rabbit $($ LE) $) /($ Total feed cost/rabbit $(L E)$.

Feed cost $/ \mathrm{kg}$ gain = Total feed cost/rabbit $($ LE $) * 1000 /$ Total weight gain/rabbit $(\mathrm{gm})$. 


\section{REFERENCES}

Agriculture Ministry Decree (1996). The standard properties for ingredients, feed additives and feed manufactured for animal and poultry. El-Wakaee El-Masria, No. 192 (1997), P 95 Amirria Press Cairo, Egypt.

AOAC (1998). Association of Official Analytical Chemists, Official methods of analysis. $15^{\text {th }}$ Edition, Published by the AOAC, Washington, D. C., USA.

Baired Parker, A.C. (1962). The occurrence and enumeration of micrococci and staphylococci in becon and on human and pig skin. J. Appl. Bact., 25: 352-361.

Cheeke, P.R. (1987). Rabbit Feeding and Nutrition. Academic Press. Orlando, Florida, USA.

Cheeke, P.R.; N. Patton and G.S. Templton (1982). Rabbit Production.5 ${ }^{\text {th }}$ Edition. The Intersate Printers and Publishers DanvilleII.

Conway, E.J. (1958). Micro-diffusion analysis and volumetric error (4 ${ }^{\text {th }}$ Ed.) The McMillan Co., New York.

Difco Laboratories Incorporated (1989). Difco manual of dehydrated culture media and reagents for the microbiology. Difco Lab., Detroit, Michigan, USA.

Duncan, D.B. (1955). Multiple ranges and multiple F-Test. Biometrics 11:42.

Eadie, J.M.; P.N. Hobson and S.O. Mann (1967). A note on some comparisons between the rumen content of barley fed steers and that of young calves also fed on high concentrate rations. J. Anim Prod., 9: 247.

Feed Composition Tables for Animal and Poultry Feedstuff Used in Egypt (2001). Technical bulletin No.1, Central Lab for Feed and Food; Ministry of Agriculture, Egypt.

Guo, X. and L. Wu (1998). Distribution of free seleno-amino acids in plant tissue of Melilotus indica L. grown in selenium-laden soils. Ecotoxicology and Environmental Safety, 39: 207-214.

Hu, C.H.; Y.L. Li; L. Xiong;H.M. Zhang; J. Song and M.S. Xia (2012). Comparative effects of nano elemental selenium and sodium selenite on selenium retention in broiler chickens, Technology, 8: 204210.

Kim, H.U. and J.M. Goepfert (1971). Enumeration and identification of Bacillus cereus in foods, 1, 24hours presumptive test edium. Appl. Microbiol. 22: 581-587.

Lansdown, A.B. (2006). Silver in health care: antimicrobial effects and safety in use. Current Problems in Dermatology, 33, 17-34.

Lodder, J. (1952). The yeasts. $1^{\text {st }}$ Ed. Pup. Inc., N.Y.

Philip, S. Rawson (1984). Ceramics. University of Pennsylvania Press. ISBN 0-8122-1156-1.

Postage, J.R. (1969). Viable counts and viability. In: methods in microbiology. Norris, J. R., Robbens, D.W. (eds), vol. 1. Academic Press, London, N.Y.: 611-628.

O’Dell, B.L. (1992). Zinc plays both structural and catalytic roles in metalloproteins. Nutrition Reviews, 50: $48-50$.

Okunlola, D.O; T.O. Akande and H.A. Nuga (2015). Haematological and Serum Characteristics of Broiler Birds Fed Diets Supplemented with Varying Levels of Selenium Powder. Journal of Biology, Agriculture and Healthcare, 5 (1): 107-110.

SAS (2001). SAS user's Guide: Statistics, SAS Institute, Inc, cray .N.C.

Selim, N.A; N.L. Radwan; S.F.Youssef; T.A. Salah Eldin and S. AboElwafa (2015). Effect of inclusion inorganic, organic or Nano selenium forms In broiler diets on growth performance, carcass and meat characteristics. International Journal of Poultry Science, 14 (3): 135-143.

Shi, L.; X.Wenjuan; Y. Wenbin; Z.Chunxiang ;R. Youshe; L.Qiang ;W. Qian and S. Lei (2011). Effect of elemental nano-selenium on feed digestibility, rumen fermentation, and purine derivatives in sheep Animal Feed Science and Technology, 163: 136-142. 
Swanson, K.S.; C.M. Grieshop; G.M. Clapper; R.G.Jr. Shields; T.. Belay; N.R. Merchen and G.C.Jr. Fahey (2001). Fruit and vegetable fiber fermentation by gut microflora from canines. J. Anim. Sci., 79(4): 919-926.

Vallee, B.L. and D.S. Auld (1990). The metallobiochemistry of zinc enzymes, in: MEISTER, A. (Ed) Advances in Enzymology, pp. 283-429, New York, John Wiley.

Wang, H., Zhang, J. and H. Yu (2007). Elemental selenium at nano size possesses lower toxicity without compromising the fundamental effect on selenoenzymes: comparison with selenomethionine in mice. Free Radic. Bio. Med., 42: 1524-1533.

Xin-Yan Han (2012).Oral evaluation in rabbits of cyclosprin-loaded Eudragit RS or RJ, nanoparticles. International Journal of pharmacy, 288: 169-175.

Zhang, J.S., X.Y. Gao, L.D. Zhang and Y.P. Bao (2001). Biological effects of a nano red elemental selenium. Biofactors, 15: 27-38.

Zhang, J.S., H.L. Wang, X.X. Yan and L.D. Zhang (2005). Comparison of shortterm toxicity between Nano-Se and selenite in mice. Life Sci., 76: 1099-1109.

Zhang, J.S., X.F. Wang and T.W. Xu (2008). Elemental selenium at nano size (Nano-Se) as a potential chemopreventive agent with reduced risk of selenium toxicity: comparison with Semethylselenocysteine in mice. Toxicol. Sci., 101: 22-31.

\title{
تأثير أضافة بعض العناصر النادرة في صورة النانووالصورة العادية في علائق الأرانب النامية
}

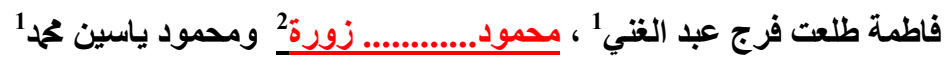 \\ 1 معهل بحوث الإنتاج الحيوانسي- مركز البحوث الزراعية - هزارة الزراعةـ الدقي-الجبزة- مصر. \\ $2{ }^{2}$
}

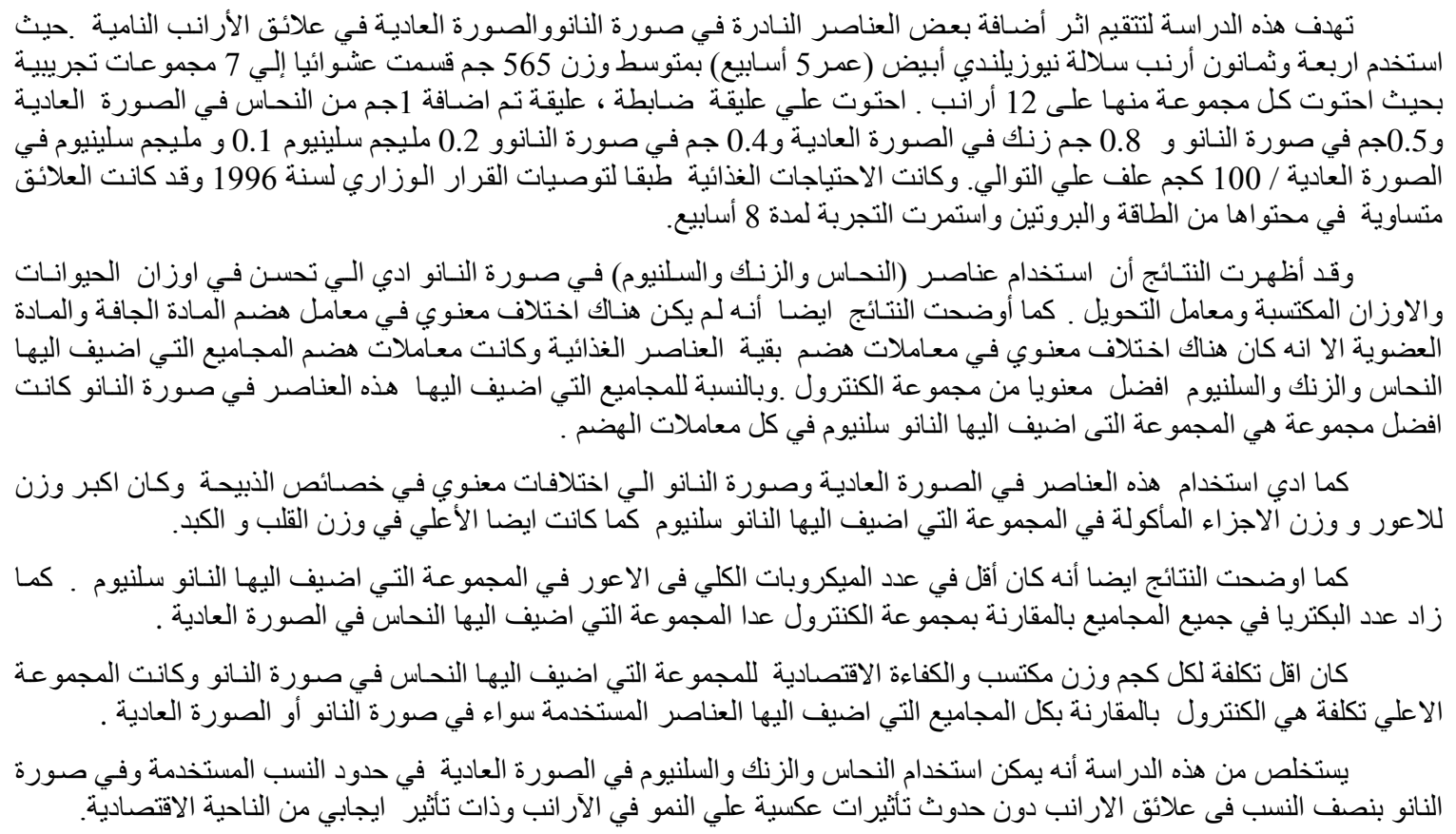

